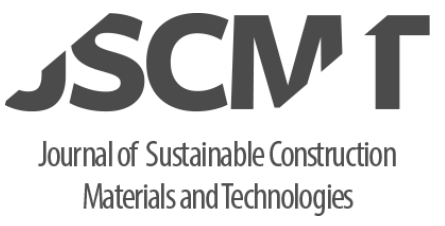

Sustain. Construct. Mater. Technol. 5(2) (2020) 467-474
Journal of Sustainable Construction Materials and Technologies

\title{
A Statistical Evaluation of Housing Preference in Istanbul Urban Transformation
}

\author{
İsmail Cengiz Y1lmaz ${ }^{\mathrm{a}}$ *

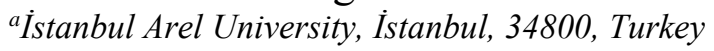

Manuscript Received June 5, 2020; Accepted August 4, 2020

\begin{abstract}
With its rapidly growing population in the last 50 years, Istanbul is one of the cities where skewed urbanization has developed widely. The fact that crooked urbanization is an important threat that causes loss of life and property in disasters such as earthquake, flood, erosion, fire etc., paved the way for the implementation of urban transformations in accordance with modern urbanism in this city. It is also very important to meet the demands and needs of those living in areas where urban transformations are applied. In this study, a housing preference survey was conducted for residents in an urban transformation area in Istanbul and it was analyzed socially and structurally as to what expectations were expected from the renewed houses. The study was carried out by randomly sampling method and face-to-face interview with 598 participants residing in an urban transformation area in Istanbul province by applying 18 survey questions. The questions are generally related to the properties of the house and the environment of the residence. SPSS v17.0 package program was used to analyze the data in this sense. In addition, independent sample t-test and one-way analysis of variance (One - Way Anova) were applied. Obtained results show that revealing different demands and needs in participants of different qualifications is quite remarkable.
\end{abstract}

Keywords: Urban Transformation, Construction Management, Housing Preference, Property Management

\section{Introduction}

The need for shelter has been one of the greatest needs of human beings for centuries. The construction industry, which is a sector that is constantly evolving and varies by adapting to the environment, still maintains its importance in line with the demands arising from this mandatory need. The urbanization problem that started after the industrial revolution became unavoidable and brought along important problems such as the increase in the number of dwellings. This congested and disorganized order has rised the problem of skewed urbanization over time. The concept of 'Urban Transformation', which is a planned intervention to prevent such problems, has been a phenomenon in recent years. Urban transformation can be expressed as a comprehensive vision and action that tries to provide a permanent solution to the economic, physical, social and environmental conditions of a region undergoing change in order to produce solutions to urban problems (Şişman et al. 2009). There are three important turning point of urban transformation in Turkey. These are migration from rural to urban, rapid urbanization and the transformation process that started in the slum areas as a result of the improvement-development plan that started in the 1980s. Another factor is the 'Law on the Transformation of Areas under Disaster Risk' No. 6306, which came into force in 2012. As a result of the enforcement of this law, risky areas were quickly announced in the cities.

\footnotetext{
* Corresponding author.

E-mail address: cengizyilmaz@ arel.edu.tr (İ.C. Yilmaz)

https://doi.org/10.29187/jscmt.2020.50
} 

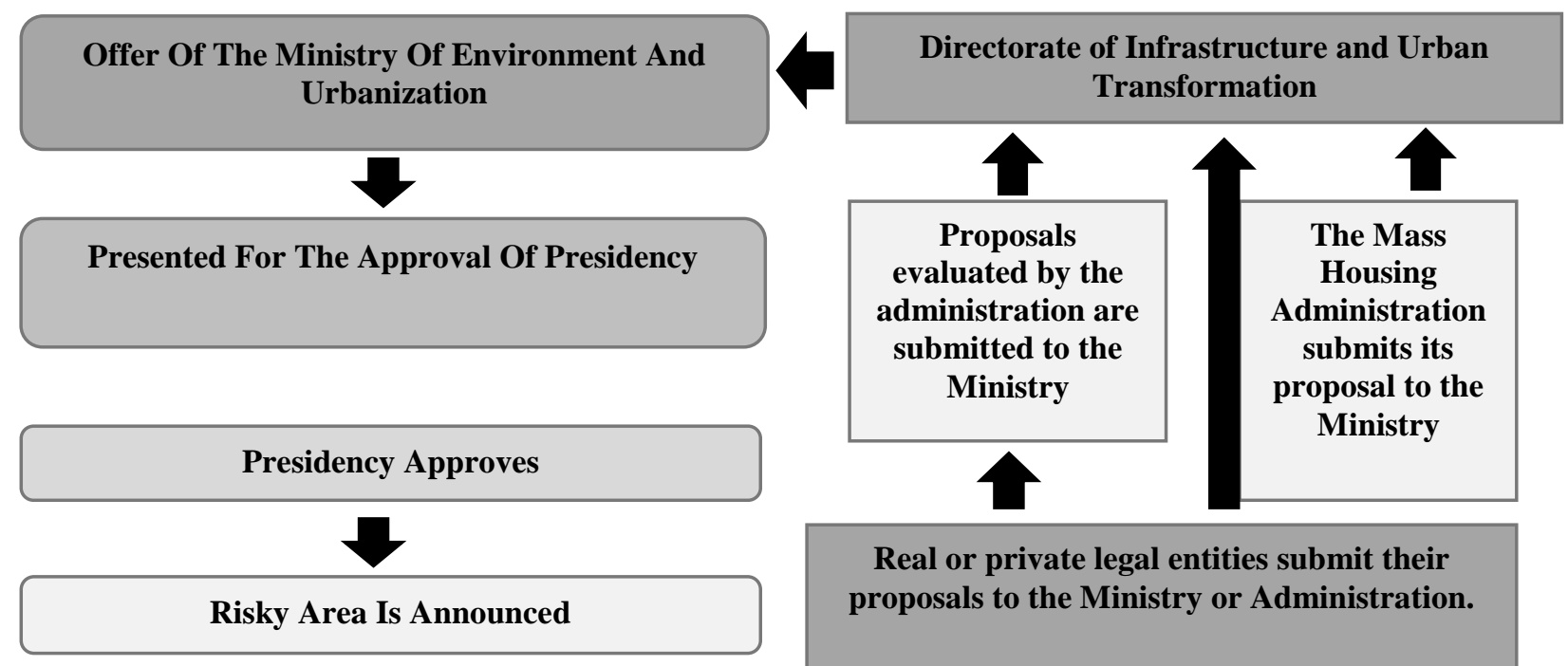

Real or private legal entities submit their proposals to the Ministry or Administration.

Fig 1. Risky Area Announcement (Ministry of Environment and Urbanization, 2018).

According to the Ministry of Environment and Urbanization, a total of 65 risky areas were declared in 23 districts of Istanbul and 120 thousand independent sections were included in the urban transformation. Urban transformation projects are practices that are discussed and criticized whether or not the satisfaction and expectations of the people who experience this practice in response to their service are met. For example; field identification, projects, entitlement and lease benefits are the central issues of this discussion and criticism. Urban transformation is not only applied in high risk residential areas but also applied in renovation and transformation areas for low and unqualified structures. Urban transformation should not only be perceived as a new development plan. At the same time, it is to make the existing building stock and city identity suitable for the needs by preserving. Urban transformation in Turkey can also be evaluated as a whole of the studies carried out to prevent big results due to the rapid and uncontrolled growth of urbanization problems that started slowly. Irregular urbanization process began in the 1950s in Turkey, increased gradually until the 1980s and started to be intense in the last half of the 1990s. The 1999 Marmara Earthquake had a great share in the start of voicing of urban transformation frequently in Turkey. Even though İstanbul is at risky earthquake zone, recent researches show that buildings are not in a good condition yet (Olbak et al., 2016). Thus, awareness about urban regeneration, reconstruction and repair works that were ignored since this date has risen again. The urban transformation movement that gained speed after 2000s has been started to be handled for a large research universe in Turkey such as urban transformation studies; selection and transformation of urban transformation areas (Çelik, 2017), methodological approach in the implementation of urban transformation (Ataöv et al., 2007; Boyraz et al., 2014; Y1lmaz, 2019), government fundings for urban transformation (Akman et al., 2018), applicability and dimensions of urban transformation (Özden, 2006; Ertaş, 2011), the impact of urban transformation projects on urban identity (Demirsoy, 2006; Demirel, 2018), quality of life before transformation in urban transformation areas (Okumuş-Eyüpoğlu, 2015; Kahraman et al., 2017) and global examples in urban transformation (Demirsoy, 2006; Aydın et al., 2016).

Urban transformation is a renewal movement that is addressed not only for Turkey but also globally. In this respect, there are many global studies in urban transformation such as the urban transformation of the developing world (Montgomery, 2008), advancing sustainable urban transformation (McCormick et al., 2013), the politics of rapid urban transformation (Grandin et al., 2018), urban transformation from public and private space to spaces of hybrid character (Nissen, 2008), the quiet demography of urban transformation (Buzar et al., 2005). However, Owied (2018) reviewed the Urban Renewal Projects of Alnajaf City Center. Jain (2018) also investigated the distance effect on urban transformation in the Capital Region of India by using spatial data and recently released census data on employment and urban amenities. Wirth et al. (2018) suggested and outlined an approach that combines green infrastructure for the urban transformation with specific concepts of post-mining landscapes. Researches do not only conclude physical space transformation, but are also concerned with sociocultural and economical impacts of urban transformation. 
The purpose of this research is to determine the relations between the socio-cultural features of the people who are within the scope of urban transformation projects and the structural and economic qualities that they expect in their residences after transformation in line with certain variables.In the scope of this study, a questionnaire was conducted with the participants at a pilot region in Istanbul, whose residences will be renewed with urban transformation. The questions asked in the survey were determined through a workshop with three city planners, five architects, two civil engineers and two sociologists. For this purpose, in addition to demographic questions, the following questions were asked.

1. What type of your renewed house should it be?

2. How many rooms would you request in your renewed house?

3. What should be your price range?

4. Is credit eligibility important to buy a house?

5 . Does it matter which construction company it made?

6. On which floor should the apartment be?

7. How important is home security?

8. How important are neighborhood relationships?

9. How important is the exterior design?

10. How important is the distance to the city center?

11. How should the internal structure of the house be?

12. On which facade should your apartment be?

\section{Materials and Methods}

In this research, a survey study, one of the statistical methods with fast results and open to evaluation and interpretation, was applied survey applications have certain sensitivity and rules. The identities of the people who answered the questionnaire were kept confidential in order to get clear and objective answers to the questions posed. Survey studies can be divided into 4 separate groups. These are face-to-face survey, internet survey, telephone survey and mail surveys. In this study, the face-to-face survey method was chosen, so that the respondents were able to change their answers when asked to check their answers. The research universe consists of people residing in the province of Istanbul, whose residences were selected as candidates for transformation within the scope of the urban transformation project. The research was carried out in the pilot region with 598 participants out of 752 people tried to be contacted. The participant selection was conducted by random sampling. There was a problem in the selection of samples that could represent the universe. Because Istanbul is a cosmopolitan city that includes people with very different income, cultural and social differences. However, the group of people in potential urban transformation areas is close to homogeneous. Therefore, different experiments with different groups were included in the sample selection. Information on the demographic characteristics of the survey participants in the study sample are given in the tables below.

$280(46.8 \%)$ of the 598 participants in the study were women and $318(53.2 \%)$ were men as seen at Table.1. Also the distribution of the numbers of the participants by age groups is shown in Table 2 .

Table 1. Genders of the participants

\begin{tabular}{ccc}
\hline Gender & Frequency & $\%$ \\
\hline Female & 280 & 46.8 \\
Male & 318 & 53.2 \\
Total & 598 & 100.0 \\
\hline
\end{tabular}

Table 2. Age groups of the participants

\begin{tabular}{ccc}
\hline Age Groups & Frequency & $\%$ \\
\hline $18-25$ & 124 & 20.7 \\
$26-33$ & 218 & 36.5 \\
$34-41$ & 93 & 15.6 \\
$42-49$ & 80 & 13.4 \\
$50-57$ & 58 & 9.7 \\
$58-65$ & 18 & 3.0 \\
$66-73$ & 4 & 0.7 \\
$>74$ & 3 & 0.5 \\
Total & 598 & 100.0 \\
\hline
\end{tabular}

In Table 3, it can be seen that the majority of the 598 participants who participated in the research consisted of $235(39.3 \%)$ high school graduates and $194(32.4 \%)$ university graduates. 
Table 3. Education Status of the participants

\begin{tabular}{lll}
\hline Graduated from & Frequency & $\%$ \\
\hline Primary school & 77 & 12.9 \\
Elementary School & 66 & 11.0 \\
High School & 235 & 39.3 \\
University & 194 & 32.4 \\
Master or PhD Degree & 26 & 4.3 \\
Total & 598 & 100.0 \\
\hline
\end{tabular}

In Table 4, it is seen that out of 598 participants who participated in the study, 360 were married $(60.2 \%)$ and 238 were single $(39.8 \%)$.

Table 4. Marital Status of the participants

\begin{tabular}{ccc}
\hline Marital Status & F & $\%$ \\
\hline Married & 360 & $\% 60.2$ \\
Single & 238 & $\% 39.8$ \\
Total & 598 & $\% 100$ \\
\hline
\end{tabular}

In Table 5, it is seen that 180 of the participants have no children (30.1\%), 295 have 1 or 2 children (49.9\%), and 123 have 3 or more children $(20.6 \%)$.

Table 5. Number of children that participants have

\begin{tabular}{ccc}
\hline Number of children & F & $\%$ \\
\hline 0 & 180 & $\% 30.1$ \\
$1-2$ & 295 & $\% 49.9$ \\
$3+$ & 123 & $\% 20.6$ \\
Total & 598 & $\% 100$ \\
\hline
\end{tabular}

\section{Results}

Descriptive statistics, One-Way Anova and T tests were applied on the SPSS software program to try to find answers to the sub-problems in the study. The sub-problem in the study was expressed as "Is there a significant difference between the number of rooms demanded and the number of children?". In order to find answers to this sub-problem, the distribution of people who requested different numbers of rooms according to the number of children they have was evaluated with anova test. Data for this subproblem are presented in Table 6.

Table 6. ANOVA results for the difference between the number of rooms demanded and the number of children.

\begin{tabular}{cccccc}
\hline $\begin{array}{c}\text { Number of } \\
\text { children }\end{array}$ & $\mathrm{N}$ & $\overline{\mathrm{x}}$ & Std.Dev. & $\mathrm{F}$ & $\mathrm{p}$ \\
\hline 0 & 180 & 3.22 & 0.706 & & \\
$1-2$ & 295 & 2.98 & 1.213 & 7.316 & $0.001^{*}$ \\
$3+$ & 123 & 3.41 & 1.280 & & \\
Total & 598 & 3.14 & 1.113 & & \\
\hline
\end{tabular}

$* \mathrm{p}<0.05$

When Table 6 is analyzed, a significant change was found between the number of rooms requested and the number of dependent children. $(\mathrm{P}<0.05)$ Based on this finding, the groups that differ significantly among themselves are those who do not have children and have a child, and those who have 1 child and 2 or more children. Cohen's d value was calculated as 0.47 when the effect size between those who had no children and those who had a child was calculated. Accordingly, the effect size is medium. Cohen's d value was calculated to be 0.34 when the effect size between a child and two or more children was calculated. Accordingly, it can be said that the meaningful difference between having a child and having two or more children is at a medium level. Another sub-problem in the research was expressed as "Is there a significant difference between the importance given to neighborhood relations and the occupation?" In order to find an answer to this sub-problem, the importance given by the people of different professions to neighborhood relations was evaluated with the ANOVA test. Data for this subproblem are presented in Table 7. 
Table 7. ANOVA Results Regarding the Change of the Importance of Neighborhood Relations Based on Occupation

\begin{tabular}{cccccc}
\hline Occupation & $\mathrm{N}$ & $\overline{\mathrm{x}}$ & Std.Dev. & $\mathrm{F}$ & $\mathrm{p}$ \\
\hline Student & 23 & 3.17 & 1.302 & & \\
Akademic Staff & 20 & 2.95 & 1.91 & & \\
Worker & 253 & 3.36 & 1.497 & & \\
Officer & 1771 & 3.33 & 1.102 & $0.000^{*}$ \\
House wife & 54 & 4.48 & 0.986 & & \\
Engineer & 38 & 3.97 & 0.885 & \\
Architect & 10 & 3.80 & 0.919 & \\
Technician & 12 & 4.00 & 0.953 & \\
Other & 17 & 3.76 & 0.970 & \\
Total & 598 & 3.50 & 1.337 & & \\
\hline
\end{tabular}

$* \mathrm{p}<0.05$

When Table 7 is examined, it is seen that the importance given to neighborhood relations is in a significant change depending on the professions $(\mathrm{p}<0.05)$. Depending on this finding, housewife - academic, housewife worker, housewife - administrative, housewife - student, administrative - engineer groups show a significant difference between them and have a $0.71,0.62,0.78,0.80$, and 0.45 Cohen's d value respectively that means the effect sizes change from medium to great levels. In order to find an answer for another sub-problem, "Do house preferences differ depending on age groups?", housing preferences of people in different age groups were evaluated with anova test. Data for this sub-problem are presented in Table 8.

Table 8. ANOVA Results on the Change of Housing Preferences by Age Groups

\begin{tabular}{ccccccc}
\hline Group No & Age Groups & $\mathrm{N}$ & $\overline{\mathrm{x}}$ & Std. Dev. & $\mathrm{F}$ & $\mathrm{p}$ \\
\hline 1 & $18-25$ & 124 & 2,17 & 0,843 & & \\
2 & $26-33$ & 218 & 2,56 & 0,959 & & \\
3 & $34-41$ & 93 & 2,48 & 0,904 & & \\
4 & $42-49$ & 80 & 2,44 & 0,726 & 5,061 & \\
5 & $50-57$ & 58 & 2,16 & 0,410 & & \\
6 & $58-65$ & 18 & 3,11 & 1,079 & & \\
7 & $66-73$ & 4 & 2,50 & 0,577 & & \\
8 & $>74$ & 3 & 3,00 & 0,000 & & \\
\hline
\end{tabular}

$* \mathrm{P}<0.05$

When Table 8 is analyzed, it was seen that housing preferences vary significantly according to age groups $(\mathrm{p}<0.05)$. Accordingly, the groups showing significant difference between them are 1-8, 2-8, 3-8, 4-8, 5-8, 2-5, 1-2 groups which have $1.39,0.64,0.81,1.09,2.89,0.54$ and 0.43 Cohen' $d$ value which means the effect sizes change from medium to great levels.

Is the importance given to distance from center according to occupational groups show a significant difference? The data for this sub-problem are given in Table 9.

Tablo 9. ANOVA Results Regarding the Change of Given Importance to the City Center Distance According to the Occupational Groups

\begin{tabular}{cccccc}
\hline Occupation & $\mathrm{N}$ & $\overline{\mathrm{x}}$ & Std.Dev. & $\mathrm{F}$ & $\mathrm{p}$ \\
\hline Student & 23 & 2,52 & 0,947 & & \\
Akademic Staff & 20 & 2,60 & 1,465 & & \\
Worker & 253 & 2,40 & 1,040 & & \\
Officer & 171 & 2,83 & 1,063 & & \\
House wife & 54 & 2,67 & 0,952 & 2,510 & \\
Engineer & 38 & 2,47 & 1,109 & & \\
Architect & 10 & 2,50 & 1,080 & \\
Technician & 12 & 2,25 & 0,754 & \\
Other & 17 & 2,76 & 0,970 & & \\
Total & 598 & 2,57 & 1,061 & & \\
\hline
\end{tabular}

$* p<0.05$ 
Table 9 shows a significant difference between worker and administrative occupation groups. When the effect size of these groups was calculated, Cohen's d value was found to be 0.40 . According to this, the effect size between the groups is medium.

ANOVA analysis results for the sub-problem of "Is there a significant difference between the desired floor number of the house by age groups?" are presented in Table 10.

\begin{tabular}{cccccc}
\multicolumn{6}{c}{ Table 10. ANOVA Results Regarding the Change of desired floor number of the house by age groups } \\
\hline Age Groups & $\mathrm{N}$ & $\overline{\mathrm{x}}$ & $\mathrm{SS}$ & $\mathrm{F}$ & $\mathrm{p}$ \\
\hline $18-25$ & 124 & 2,44 & 0,990 & & \\
$26-33$ & 218 & 2,50 & 1,234 & & \\
$34-41$ & 93 & 2,46 & 1,079 & 2,498 & \\
$42-49$ & 80 & 2,20 & 0,786 & \\
$50-57$ & 58 & 2,14 & 0,634 & \\
$58-65$ & 18 & 2,17 & 1,295 & \\
$66-73$ & 4 & 1,50 & 0,577 & \\
$>74$ & 3 & 1,00 & 0,000 & \\
Total & 598 & 2,38 & 1,066 &
\end{tabular}

As it is seen at Table 10, there is a significant difference between the desired floor number of the house by age groups. Accordingly, groups that differ significantly between are 1-8, 2-8, 3-8, 4-8, 5-8, 6-8, 1-8. When the effect size of the significant difference between these groups was calculated, Cohen's d value was found to be $2.05,1.71,1.91,2.15,2.34$ and 1.27 respectively. These results show that the effect degree between the groups is large. The sub-problem of "Does the importance of home security show a significant difference depending on gender?" was evaluated by independent sample t-test. Data for this subproblem are given in Table 11.

Table 11. Independent Sample t-test Results Regarding the Change of the importance of home security by gender

\begin{tabular}{ccccccc}
\hline Gender & $\mathrm{N}$ & $\overline{\mathrm{x}}$ & $\mathrm{Std}$. Dev. & SD & $\mathrm{t}$ & $\mathrm{p}$ \\
\hline Female & 280 & 4.41 & 0.896 & 561 & 9.568 & $0.000^{*}$ \\
Male & 318 & 3.54 & 1.318 & & & \\
\hline$* \mathrm{p}<0.05$ & & & & & &
\end{tabular}

$* \mathrm{p}<0.05$

If Table 11 is examined, the importance of home security according to gender differs significantly $\left(\mathrm{t}_{561}=9.568\right.$, $\mathrm{P}<0.05)$. According to this, it can be stated as women attach more importance to home security than men by looking at the averages $(4.41>3.54)$. Cohen's d coefficient was found 0.77 . Accordingly, it can be said that the effect size is at a great level.

The sub-problem, "Is the number of rooms demanded shows a significant difference depending on marital status?" was evaluated by using independent sample t-test. The data for this sub-problem are presented in Table 12.

Table 12. Independent Sample t-test Results Regarding the Change of the number of rooms demanded by marital status

\begin{tabular}{ccccccc}
\hline Marital Status & $\mathrm{N}$ & $\overline{\mathrm{x}}$ & Std.Dev. & SD & $\mathrm{t}$ & $\mathrm{p}$ \\
\hline Married & 360 & 3.43 & 1.035 & 596 & 8.251 & $0.000^{*}$ \\
Single & 238 & 2.71 & 1.086 & & & \\
\hline$* \mathrm{p}<0.05$ & & & & & &
\end{tabular}

$* \mathrm{p}<0.05$

When Table 12 is examined, the change in the number of rooms requested due to marital status shows a significant difference $\left(\mathrm{t}_{596}=8.251, \mathrm{p}<0.05\right)$. Accordingly, considering the averages, it can be said that the number of rooms requested by married people is higher than single people $(3.23>2.71)$. In line with these results, Cohen's coefficient was found to be 0.67 when the effect size was calculated. Accordingly, it can be said that the effect size is at a medium level.

The sub-problem of "Does the importance given to exterior design show a significant difference depending on gender?" was analyzed by independent sample t-test. Data for this subproblem are given in Table 13. 
Table 13. Independent Sample t-test Results Regarding the Change of Given importance to the exterior design by gender.

\begin{tabular}{ccccccc}
\hline Gender & $\mathrm{N}$ & $\overline{\mathrm{x}}$ & Std.Dev. & SD & $\mathrm{t}$ & $\mathrm{p}$ \\
\hline Female & 280 & 3.87 & 1.125 & 593 & 9.675 & $0.000^{*}$ \\
Male & 318 & 2.88 & 1.370 & & & \\
\hline
\end{tabular}

$* \mathrm{p}<0.05$

When Table 13 is examined, the importance given to exterior design shows a significant difference depending on gender $\left(\mathrm{t}_{593}=9.675, \mathrm{p}<0.05\right)$. If the averages are compared according to the table 13 , it can be said that women attach more importance to exterior design than men

(3.87 > 2.88). If the effect size is calculated, Cohen's $d$ value was found to be 0.78 . Accordingly, the effect size is large.

\section{Conclusion}

In this study, it was aimed to determine the criteria and expectations of the people living in urban transformation areas about their housing preferences in line with certain variables. The important point in this study is to make evaluations on the variables which may be effective in housing choice in urban transformation. The results obtained from the research are briefly summarized below.

- It is observed that the number of rooms requested varies significantly depending on the number of children owned. Naturally, an increase was observed in the number of desired rooms as the number of children owned.

- It was concluded that the importance given to neighborhood relations varies significantly depending on occupational groups. When looking at the differences, significant differences were observed between housewives and other professional groups. This is because of housewives spend more time at home and have more time to communicate with neighbors than other groups.

- It has been observed that there is a significant difference in relation to the change in housing preferences according to age groups. When the groups that differ among them are examined, it is seen that the prominent group is the group of 74 and over. It can be said that the higher age group preferred more medium-sized apartment-style buildings rather than residences.

- According to the occupation groups, the importance given to the distance to city center showed a statistically significant difference. Groups that differ significantly among them are officers and other professional groups. It can be said that the importance given to the distance from the center is higher in the officer group, since the reason is that institutional firms are mostly in the city center.

- Significant differences were observed between the house floor number request by age groups. When the differences between the groups are examined, it shows that lower floors are preferred due to ease of access as the age range increases.

- It has been observed that women care more about home security than men.

- Considering the differences between the number of requested rooms and marital status, it was observed that married people requested more number of rooms than single people.

- It has been observed that women give more importance to exterior design than men.

According to these results; Suggestions that can be considered during the production of housing in the urban transformation process can be presented as follows;

- The expectations and attitudes of the people residing in urban transformation areas should be determined and a transformation policy should be followed in line with these criteria.

- The wishes of different age groups should be considered. For example, the use of elevators depending on the height of the building should be supported or if there are stairs at the entrance of the building, the use of ramp should be taken into consideration. Access to the house should be as easy as possible.

- Home security should be given as much attention as possible. Otherwise, the expectations of the household, who adopt a restless lifestyle, will not be met as much as desired.

- The importance of neighborhood relations in urban transformation is an undeniable fact. It is important to protect the urban identity and social relations in the areas to be transformed.

- The areas to be transformed should be designed without isolating from the city and should not be applied in a way that causes social segregation. 
With the future studies by diversifying the methodology carried out in this study by considering different demands in different regions, more ideas can be obtained about the choice of housing in urban transformation.

\section{References}

1. Şişman, A., Kibaroğlu D. (2009). Dünya'da ve Türkiye'de Kentsel Dönüşüm Uygulamaları, TMMOB Harita ve Kadastro Mühendisleri Odası 12. Türkiye Harita Bilimsel ve Teknik Kurultay1, 11-15 Mayıs 2009, Ankara.

2. Çelik, K. (2017). Kentsel Dönüşüm Alanlarının Seçimi ve Dönüştürülmesine Yönelik Örnek Bir Uygulama, Gümüşhane Üniversitesi Fen Bilimleri Enstitüsü Dergisi, 7(2), p.221 - 235.

3. Ataöv A., Osmay S. (2007). Türkiye'de Kentsel Dönüşüme Yöntemsel Bir Yaklaşım, METU Journal of The Faculty of Architecture, 24(2), p.57-82

4. Boyraz Z., Hoş B.Y. (2014). Türkiye'de Kentsel Dönüşüm Uygulamaları, Journal Of World Of Turks, 6 (3), p.45-63.

5. Yılmaz O.K. (2019). Türkiye'de Kentsel Dönüşümün Uygulayıcı Aktörleri ve Yaptıkları Çalışmaların Sayısal Verileri, Marmara Türkiyat Araştırmaları Dergisi 6(2), p. 300-316

6. Özden P.P. (2006). Türkiye'de Kentsel Dönüşümün Uygulanabilirliği Üzerine Düşünceler, Istanbul Üniversitesi Siyasal Bilgiler Fakültesi Dergisi, 35(2006), p.215-233.

7. [7] Olbak M., Naimi S. (2016). Kentsel Dönüşüm Uygulanmış 5 Katlı İki Yapı Örneğinin Deneysel Verileri Kullanılarak Doğrusal Olmayan Analiz Yöntemleri İle Güçlendirme Sonuçlarının İrdelenmesi, Ístanbul Aydın Üniversitesi Dergisi, 31(2016), p.145-166.

8. Ertaş M. (2011). Kentsel Dönüşüm Çalışmalarında Sosyal Boyutun İncelenmesi, Ankara- Londra Örnekleri, Selçuk Teknik Dergisi, 10(1)-2011, p.1-18.

9. Demirsoy MS. (2006). Kentsel Dönüşüm Projelerinin Kent Kimliği Üzerindeki Etkisi (Lübnan, Beyrut, Solidere Kentsel Dönüşüm Projesi Örnek Alan İncelemesi), Mimar Sinan Güzel Sanatlar Üniversitesi, Fen Bilimleri Enstitüsü, Şehir ve Bölge Planlama Anabilim Dalı, Kentsel Tasarım Yüksek Lisans Tezi.

10. Demirel D. (2018). Kentsel Dönüşüm, Pamukkale Üniversitesi Sosyal Bilimler Enstitüsü Dönem Projesi, Denizli.

11. Okumuş D.E., Eyüboğlu E.E. (2015). Kentsel Dönüşüm Öncesi Kentsel Yaşam Kalitesi Araştırmasına Yönelik Yöntem Önerisi ve Ataşehir Barbaros Mahallesi Örneklemi, TMMOB Şehir Plancıları Odası Planlama Dergisi, 25(2), p.93-106.

12. Kahraman Z.E., Özdemir S.S. (2017) Kentsel Dönüşümü Gündeme Gelen Bir Alan İçin Konut Memnuniyeti Araştırması: Türk-iş Blokları Örneği, Megaron Yıldız Teknik Üniversitesi Mimarlık Fakültesi E-Dergisi, 12(4), p.619-634.

13. Aydın A.H., Çamur Ö. (2016). Kentsel Dönüşüm Uygulamalarında Başarılı Dünya Örnekleri: Danbara, Solidere, Rio De Janeiro; Kahramanmaraş Sütçü Imam Üniversitesi İktisadi ve Ídari Bilimler Fakültesi Dergisi, 6(1), p.53-68.

14. Montgomery M.R. (2008). The Urban Transformation of the Developing World, Science, 319(5864), pp. 761-764.

15. McCormick K., Anderberg S., Coenen L., Neij L. (2013). Advancing Sustainable Urban Transformation, Journal of Cleaner Production, 50(2013), p. 1-11.

16. Grandin J., Haarstad H., Kjærås K., Bouzarovski S. (2018). The politics of rapid urban transformation, Current Opinion in Environmental Sustainability, 31(2018), p. 16-22.

17. Nissen S.(2008). Urban transformation from public and private space to spaces of hybrid character, Czech Sociological Review, 44(6), p.1129-1149.

18. Buzar S., Ogden P.E., Hall R. (2005). Households matter: the quiet demography of urban transformation, Progress of Human Geography, 29(4), p.413-36.

19. Owied H.S. (2018). Urban transformations of historical cities centers: Urban renewal projects of Alnajaf city center, 2018 International Conference on Advance of Sustainable Engineering and its Application (ICASEA), Wasit, p. 159-164, doi: 10.1109/ICASEA.2018.8370975.

20. Jain M. (2018). "The effect of distance on urban transformation in the Capital Region, India, International Planning Studies, Taylor \& Francis Journals, 23(1), p. 37-50.

21. Wirth, P., Chang, J., Syrbe, R., Wende W., Hu T. (2018). Green infrastructure: a planning concept for the urban transformation of former coal-mining cities. Int J Coal Sci Technology, 5(2018),p.78-91. 